\title{
Is There an Anticorruption Agenda in Utilities?
}

\author{
Charles Kenny ${ }^{1}$
}

Draft

\begin{abstract}
In a networked utility setting (few, predominantly monopoly providers), it is very hard to measure the extent of grand corruption using perceptions or surveys. It is even harder to measure the extent of damage done specifically by corruption, petty or grand. As a result, it will be hard to develop 'actionable indicators' of, or to develop empirically tested responses to, corruption in utilities. How much does this matter? Corruption is the result of a failure of governance. We can measure the impact of poor governance at the level of the utility, and we have a number of tools to improve their governance. It is not clear that, at the sectoral or company level, there is a significant anticorruption agenda not encompassed by this broader agenda of improved governance. To that extent, the 'new' anticorruption agenda provides renewed justification for the 'old' focus on institutions at the level of utilities management, but does not require a radically different approach.
\end{abstract}

\footnotetext{
${ }^{1}$ Senior Economist, the World Bank, ckenny@worldbank.org. The views expressed are the author's own, and do not necessarily represent those of the World Bank, its Executive Directors, or the countries that they represent.
} 


\section{Introduction}

A focus on corruption's impact on development has grown over the past fifteen years, with the launch of the NGO Transparency International in 1993, the 1997 OECD Convention on Combating Bribery of Foreign Public Officials in International Business Transactions and the 2003 United Nations Convention Against Corruption. Academics and researchers have also taken a greater interest in the subject --in part because of a proliferation of data including Transparency International's perceptions indices as well as business and customer surveys asking about the extent of bribery.

This interest has filtered down to the sectoral level, with donor-backed global initiatives launched or forthcoming in the areas of extractive industries (EITI, launched in 2002), pharmaceuticals and construction (META and CoST, being launched in 2007) alongside private-sector led anti-corruption initiatives including the World Economic Forum's Partnership Against Corruption in Industry (PACI) and the Kimberly process covering conflict diamonds for example. Similarly, academic analysis has focused on the sectoral impact of corruption, not least in health (Lewis, 2006) and education (Rekinna and Svennson, 2006) as well as the impact of corruption on roads projects (Olken, 2004).

Utility industries have been comparatively lightly touched both by global initiatives and by academic analysis. A few pathbreaking academic papers include Tanzi and Davoodi (1998) and Estache et. al. (2006), which both study the links between corruption perceptions and utility outcomes, Davis (2003) who surveys corruption in water utilities in South Asia and Clarke and Xu (2004) who link cross-country measures of petty corruption with utility competition in East Asia and Central Asia.

The comparatively limited research in the area of corruption in utilities means that there is limited empirical evidence to support particular corruption-focused responses. To a great extent, the answer to the question "what approaches work to reduce the impact of corruption in utilities?" is "we don't know." Exacerbating this problem is that limited research reflects a paucity of quality data on the extent and impact of corruption in utility provision and the complexity of collecting such data.

This paper outlines the weaknesses in our ability to measure utility corruption but also suggests an answer to the resulting dilemma. We do not need to know which approaches reduce corruption but rather which governance approaches improve development outcomes in terms of extent, quality and price of provision. Here, our evidence base is far richer, in part because our ability to measure these outcomes is far stronger than our ability to measure corruption itself. It is, of course, very likely that one of the mechanisms through which governance reforms will improve outcomes is by reducing corruption. But this suggests that the anti-corruption agenda is, by and large, encompassed by the broader (older, better understood) institutional reform agenda for utilities developed over the last twenty years.

The paper begins with a case study of water provision in Jakarta which illustrates the difficulties of measuring corruption and its impact, but also that a familiar set of reforms 
might have improved outcomes in part through reducing corruption. It turns to a broader discussion of measurement of corruption at the sector level as well as the additional, perhaps insurmountable, complexities of accurately measuring the impact of that corruption. The next section discusses a more tractable agenda for measurement and improvement -that of broader governance reform. The paper briefly discusses what we know about governance reform and outcomes, focusing on competitive provision, regulation and state-owned enterprise reform. The paper concludes with lessons for the governance and anticorruption agenda in utilities.

\section{A Jakarta Case Study}

In the late 1980s, only fourteen percent of Jakarta's population lived in households connected to the municipal water system. Fully one third relied on water from street vendors. There was no 'petty corruption' in vending, in that private suppliers were abusing no public office while charging high prices to final consumers who, in turn, paid no bribes. Nonetheless, street vendor customers paid between three and fifty times as much for water as did people with a household connection. Water vendors got their supplies from public taps. There were very few of these taps $-1,200$ serving at least 2.5 million people. This increased the labor costs of the street vendors, who usually transported water using jerricans piled on handcarts. Nonetheless, the vendors were earning hourly wages two to three times the average for men with primary or lower education. The public taps were controlled by operators, who (in turn) charged three to six times their per liter costs for water.

Why were prices so high - so much higher than any reasonable calculation of labor costs and wholesale prices suggested that they should be? And why were there so few public taps? It was not that the cost of tap construction was out of reach -five to ten thousand additional taps could have been constructed for less than the price of one of the city's underutilized water treatment plants.

Instead, it appears that the street vendors were running a cartel, supported by bribes to local officials and water utility staff. After subtracting the costs of labor, equipment and payments to public tap operators, nearly one half of the price paid to vendors for water by households was unaccounted for - the assumption is that it went to cartel rents and bribes. In turn, after accounting for official payments to the utility for water and operating costs, about sixty percent of vendor payments to public tap operators were available for excess profit and bribe payments. And it appeared that the number of public taps had been optimized to maximize the rents available for water vendors and utility staff (Lovei and Whittington, 1991).

Governance in Jakarta's water sector faced additional challenges in 1997 when two European water companies, one partnering with a son of President Suharto, another with a close associate of the President, were awarded concessions for the city's water supply without a competitive bidding process. In this case, contracts allowed for limited 
financial oversight and, additionally, had to be renegotiated in the aftermath of the Asian financial crisis (Castalia, 2005).

Jakarta's experience suggests the complexity and impact of corruption. Under public provision, low income households in the city were paying as much as seven percent of their meager resources on water in the dry season -and around two thirds of that was due to the costs of collusion, bribery and skewed investment decisions related to maximizing rents. At the same time, a survey of water vendor customers would have suggested that none were paying bribes. Our evidence of the likely scale of corruption is based on calculations of producer surplus rather than direct, robust, survey evidence. In turn, the introduction of private provision sparked numerous allegations of corruption, but these remain little-substantiated.

Whilst the extent of corruption remained shrouded, it is easy to imagine a number of interventions that might have measurably improved outcomes. For example, a simple solution to the problem of cartel sales adopted by the Jakarta government was to allow any householder with a tap to sell water. As a result, end water prices to unconnected households dropped between 30 and 60 percent (Lovei and Whittington, 1991). Again, a potential solution to the swirling allegations of corruption with the introduction of private provision would have been to use an open, competitive selection procedure for the concession contract based on simple auction criteria and pre-published price, investment and quality conditions.

We can only estimate the extent of corruption under public provision, and we have only unproven allegations of corruption under private provision of water in Jakarta, then. This is hardly a level of certainty that would allow for careful analysis of the corruption impact of interventions. At the same time, especially in the case of public provision and an increased level of vendor competition, we can measure the resulting change in outputs (through prices) very clearly. Furthermore, what is clear about both proposed interventions in response (competition in supply and open competition for the concessions) is that, regardless of concerns with corruption, an institutional reform agenda focused on greater efficiency and improved outcomes for consumers would have promoted this same course of action. Expanding the role of competitive provision -competition in the market, or failing that for the market, has been a mainstay of utility reform for some time.

\section{Measuring the Extent of Corruption in Networked Utilities}

The Jakarta case study points up the complexity of accurately measuring the level of corruption in utilities. A global analysis confirms this complexity. There are few existing measures, they are partial, and they ill-capture the impact of the abuse of public office for private gain.

In 1999, the median firm in a survey of businesses in Eastern Europe and Central Asia (BEEPS) reported spending one to two percent of its revenues on unofficial payments to 
public officials. $^{2}$ Across the region, the average firm suggested that it used 15 percent of its bribe budget on securing government contracts, 11 percent to facilitation connections to utilities and two percent to influence the design of legislation or regulation. ${ }^{3}$ Such results suggest that petty bribery for infrastructure connections is somewhat of an issue in the region and that utility construction as well as regulation and concessions is probably subject to corruption as well (Kenny, 2006).

Looking at petty corruption more broadly, Davis (2003) used a survey approach to estimate that the average speed payment or bribe made to get connected to piped water in India works out at \$2.64 per legal customer (see also Seligson, 2005). Similalry, around twenty World Bank Business Environment Surveys have asked infrastructure-related questions regarding the need to pay 'gifts' in order to get a water, electricity or phone connection.

These results are useful, but appear to hide a more complex reality regarding considerable noise and variation in the survey results. For example, significant variation within countries in the reported level of petty infrastructure corruption is suggested by the 1999 BEEPS survey. The survey asks respondents how often firms like theirs have to bribe to get connected to public services such as telephone and electricity connections, with answers ranging between 'always' (given a value of one) and 'never' (given a value of six). There are notable country differences (the percentage of firms answering 'never' varies between 31 percent in Ukraine and 92 percent in Estonia). Nonetheless, the variation in answers within countries is considerably larger than the variation across countries, to the extent that the great majority of average country responses are unlikely to be statistically significantly different from each other (Kenny, 2006). Amongst other factors, this will reflect uncertainty on the part of respondents as well as different levels of bribery in different parts of the country covered by different service providers.

At the country level, the Investment Climate Survey results suggest a very high correlation between cross-country estimates of corruption in getting connections to electricity, water and telephone services, despite considerably lower correlations with a number of other corruption variables (Kenny, 2006). If the data reflects reality, it suggests that even despite the very different nature of the sectors (levels of competition, size of firms, involvement of the private sector and so on), corruption is determined almost solely by national-level factors which are unrelated to general corruption perceptions measures and yet which vary insignificantly between sectors. Perhaps more plausibly, and given that we believe that corruption does significantly vary by sector, the data may reflect a common perception driven by psychologically anchored estimates rather than very similar levels of petty corruption.

Beyond data weaknesses, utility provision in particular suffers from a lack of any (even low quality) data regarding grand corruption. We have no cross-country comparable data of the extent of bribery in infrastructure firms. BEEPS did not survey infrastructure firms, for example. This reflects in part the concentrated nature of infrastructure

\footnotetext{
${ }^{2}$ This amongst firms which reported a percentage and did not answer "don't know."

${ }^{3}$ These are unweighted country average responses.
} 
provision which adds complexity to ensuring the anonymity of survey responses. We do know that the payments involved in grand corruption in construction and provision impacting utilities can be significant. For example, in 1993, the state government of Maharashtra in India signed a 20-year power purchase agreement with Enron as part of a $\$ 3$ billion deal to build a 695MW power plant at Dabhol. The contract was negotiated without a competitive bid process and involved \$20 million in expenditures on what Enron euphemistically described as 'education and project development process' expenses. Investigations in corrupt payments linked to the Lesotho Highlands water project suggest that these totaled at least $\$ 6$ million. Average bribe payments as a percentage of construction contract values appear to range up towards ten percent (Kenny, 2006). Nonetheless, this data is subject to significant error, and we have no data at all based on survey measures of payments connected with privatizations, concessions, or infrastructure licenses or regulations, for example.

What we do know of utility corruption suggests that it is weakly correlated with general perceptions indicators. Table One presents a database on corruption in utilities based on a 58 developing country sample. These countries were selected on the grounds that they had a business environment survey which included corruption questions. The data will be used later to examine links between corruption measures and utility outcomes, here we will examine the relationship between sector corruption measures and general indicators of corruption and governance.

Figures One, Two and Three divide countries into those with low and high reported petty corruption in each utility (energy, telecommunications and water). For water and electricity, the dividing line between low and high corruption is set at 15 percent of firms reporting the need to pay bribes to get connected to the utility service, for telecommunications the dividing line is set at 10 percent (levels are set in order to approximately equalize the number of countries labeled as low and high corruption). The figures then report the average score for each group on a range of governance measures expressed as a multiple of the standard deviation of the measure for low and high corruption countries combined. A larger gap between the low and high petty corruption scores suggests a stronger relationship between petty bribery and the broad governance indicator.

In all three utilities, countries with low petty corruption in utilities perform better on Transparency International's Corruption Perceptions Index as well as the World Bank Institute's Control of Corruption measure. In energy and telecommunications, we also see the expected relationship with enterprise survey measures of the percentage of firms which suggest corruption is a significant problem. Furthermore, a measure of the extent of the requirements for businesses to publish firm information is also correlated with low corruption in all three utility sectors, and private investment is associated with lower corruption in the case of telecoms and water. Two measures of sector structure -the percentage of the fixed line incumbent which is in private hands and the level of local competition are also associated with lower corruption in telecommunications. 
Having said that, the sample is small, and correlations are weak. Looking at petty corruption in electricity and the CPI measure, the (little) available data suggests no significant correlation between perceptions of corruption in getting an electricity connection and CPI scores, for example (Kenny, 2006). Furthermore, these general governance indicators are positively correlated with GDP per capita. And amongst our 'governance indicators', it is GDP per capita that appears to be the most strongly predictive of petty corruption, suggesting that general governance indicators predict little about petty corruption in utilities that we could not predict looking at income levels alone. $^{4}$

\section{Measuring the Impact of Corruption}

We remain constrained by very limited evidence on the extent of bribery, and particularly grand corruption in the provision of utility services, then. Exacerbating this problem is that the extent of corrupt payments is only partially correlated with the economic cost of that corruption. Looking at petty corruption in the water sector, to some degree petty bribes involve payments for services that undercompensated water staff should be providing anyway -they are a transfer to get the job done, perhaps one of the least harmful forms of corruption. Compared to payments that encourage illegal activities, or payments to avoid law enforcement, payments to encourage legal activities have less impact on economic outcomes. Furthermore, compared to official connection charges of around $\$ 140$ (Franceys, 2005) or a monthly water bill in Delhi averaging about $\$ 1.29$, willingness to pay figures considerably larger and a tenfold price difference between connected and unconnected consumers, illegal connection payments averaging \$2.64 are not so significant in and of themselves. Even after speed payments, there is a considerable consumer surplus to a water connection. That corruption reduces the quality of water services and diverts connections is likely to be a far larger source of economic harm than the financial scale of petty bribes for connections.

Looking more broadly at levels of corruption in water provision in South Asia in 2001-2 Davis' (2003) survey suggested that contractors frequently paid bribes to win contracts worth between one and six percent of contract values, followed by kickbacks during construction of between 6-11 percent of the contract value, as well as forming 'sanctioned' cartels that raise prices by fifteen to twenty percent. In addition, kickbacks went in part to cover low quality work, in which materials worth between 3 and five percent of the contract value are not supplied. Assuming an economic impact of each dollar of such missing materials of between \$3-4 in terms of shorter life and limited capacity, this suggests an economic cost equal to $9-20 \%$ of already inflated contract prices. These two forms of corruption together may have raised the price of a sustainable water connection by 25 to 45 percent. Compared to total petty and grand corrupt

\footnotetext{
${ }^{4}$ It is worth noting that an analysis of BEEPS data managed to produce more significant results. It suggested that bribery was more common to get connected to electricity and telecommunications for firms in less democratic slow-growing countries with less-developed infrastructure, public ownership of utilities and limited competition (Clarke and $\mathrm{Xu}, 2002)$.
} 
financial payments per water connection of between $\$ 29$ and $\$ 69$, the economic damage of this corruption was closer to $\$ 101-\$ 181 .^{5}$

Even this amounts to a partial accounting of impact, because some of the most damaging results of corruption involve the construction of infrastructure that carries almost no economic value at all. Returning to the case of Enron in Maharashtra, we have seen that the level of bribery may have approached \$20 million --but the economic cost of the corruption approached $\$ 1.3$ billion, because the plant was never economical to run (Gulati and Rao, 2006).

Corruption in utilities is complex and multi-layered, then, and in utility provision only some forms are amenable to survey measurement. General measures of the level and extent of corrupt payments appear to be only loosely related to utility-specific corruption measures and the size of payments is, regardless, ill-designed as a measure of the economic impact of corrupt actions. Given all of this, it is perhaps unsurprising that the evidence is against a robust link between general perceptions of corruption and lower quality or extent of infrastructure. For example, Tanzi and Davoodi (1998) find some evidence linking outcomes including the frequency of power outages to measures including Transparency International's Corruption Perceptions Index. But while Estache et. al. (2006) find that while a general measure of perceived country-level corruption is associated with lower energy use, they also found telecoms access positively associated with perceived corruption while measures of access to water were not correlated either way with perceived corruption. ${ }^{6}$

In order to provide further evidence on the robustness of the relationship between corruption and utility outcomes, Table Two presents results of a simple set of regression analyses attempting to link various corruption measures with utility outcome measures controlling for GDP per capita. The first line of each regression presents the coefficient, the second a probability from a Student's t-test. Results significant at five percent are reported in bold.

It should be noted that sample sizes are frequently small and that weaknesses in the selected corruption measures are widely accepted. Nonetheless, the results confirm a fragile relationship between available measures and outcomes. Transparency International's Corruption Perceptions Index is significantly related to none of the outcomes in our sample -levels of investment, extent of access, telecoms waiting lists or transmission distribution losses. The percentage of company managers ranking corruption as a major constraint to doing business is linked to the percentage of managers who see electricity as a major constraint. While this may reflect a bias towards complaint in these surveys, some additional comfort is given by the fact that it is also correlated

\footnotetext{
5 This is assuming a $\$ 400$ cost of connection from Fay and Yepes (2003) and a \$3-4 cost per dollar of missing materials based on an estimate for road construction from Olken (2006) -which clearly needs to be treated with caution when applied to a completely different infrastructure sector.

${ }^{6}$ These results, positive and negative alike, are open to all of the usual concerns with econometric exercises regarding questions of causality and the stability of coefficients in the presence of multicolinearity and omitted variables.
} 
with lower power consumption. At the same time greater concern with corruption is positively associated with mobile phone access and insignificantly related to other variables. Similarly, there is a positive relationship between bribing in contracts and the extent of private participation in infrastructure (although again a negative relationship with power consumption). Finally, the surveyed extent of petty corruption in utility provision is only significantly negatively correlated with the percentage of the population with access to water. Overall, then, only four of these 28 regressions support a theorized relationship between corruption measures and utility outcomes.

Again, this is not to suggest that corruption does not matter to outcomes in utilities. We have considerable case-study evidence pointing the other way. For example, in Bangladesh and Orissa, in India, around 55 percent of generated power is paid for, the rest is lost to technical and commercial losses. Of this, perhaps $15-18$ percent is accounted for by 'true technical' losses, suggesting leakage due to illegal connections or underbilling accounts for as much as thirty percent of generated power. ${ }^{7}$ In Andhra Pradesh, transmission and distribution losses were reduced from 38 to 26 percent 19992003 in large part through theft control and the regularization of 2.25 million unauthorized connections (Gulati and Rao, 2006).

However, the above results do suggest that our available measures of corruption may be ill-designed to capture that impact and (as a result) ill-designed to test anti-corruption interventions for their overall efficacy, or to provide guidance for firms and development agencies looking to focus their anticorruption efforts on, or avoid working in, 'particularly corrupt' sectors. Measures of petty corruption are themselves 'outcome indicators' of course - in that they feed into the final price paid for consumers for access to services. But they are a partial measure of that outcome, and apparently a poor measure of the broader impact of corruption (or, more broadly still, weak governance) on utility performance. And measuring grand corruption in utilities is unlikely to be possible with any great accuracy even with a considerably expanded survey effort.

\section{Measuring and Improving Utility Governance and Outcomes}

Corruption is a symptom of failed governance. And minimizing the damage done by governance failures including corruption involves countering the incentives to build the wrong thing and then to build and operate it badly. We should focus attention on macrosectoral issues such as overall budgeting and project selection and on physical auditing of the status of physical capital. We should see if budgets are adequate (and paid) for operations and maintenance, if O\&M is actually carried out in a way that maintains infrastructure quality, if the process for selecting projects picks those with high economic return and if the new infrastructure is well constructed. If all of these conditions are met, we will know that the impact of corruption in utilities on overall development will be comparatively small. Because such conditions (alongside a reasonable price structure) also suggest an efficiently-run utility, they imply that there are limited rents for corrupt

\footnotetext{
${ }^{7}$ Similarly, Davis (2003) suggests that unaccounted for water accounts for 35 percent of total flows in India.
} 
agents to expropriate. If quality services are being delivered for a reasonable price, there are no resources left over for a firm to finance large bribes or an official to 'pad' expenses.

An advantage of an approach focusing on inputs and outcomes is that it is easier to find good metrics than in the case of sector- and type-specific direct corruption indicators. Rather than relying on perceptions or expert intuition, an inputs and outcomes approach can use more objective indicators. On the side of inputs, governance failures including corruption are associated with environments where government officials have considerable power and discretion in their actions and decisions and they are not held accountable -often related in part to a lack of transparency. Measures of governance that can determine these environments are comparatively widely available and easy to collect, from global indicators covering elements such as the strength of public financial management and the level of parliamentary oversight of budgets through sector measures including the level of competition and the independence of regulators to micro interventions such as the percentage of connections that are metered. At the investment level, economic evaluation should allow a determination of the status of project selection in a given sector to see if it appears to be following rational procedures or is driven by other concerns.

On the side of outcomes, we have a range of access, quality and price variables covering water, electricity and telecommunications including the percentage of households with access, the percentage of calls dropped or hours of service, and prices for connection and usage (although, to be comprehensive, price data should include both official and unofficial payments, with evidence on the latter collected through surveys). These can be augmented through the use of output measures including efficiency indicators (cubic meters of water delivered or connections per staff, transmission and distribution losses) which may help pinpoint where governance weaknesses are having their largest impact.

Of course, an approach that focuses on governance inputs and sector outcomes will commit sins of both omission and commission regarding corruption. In terms of empirical analysis, studies may suggest that a governance intervention leads to improved outcomes, but it would be a false positive to ascribe this to reduced corruption because the impact was through some other channel (improved knowledge or decreased incompetence, perhaps). Or studies may suggest that a governance intervention fails to improve outcomes, but it would be a false negative to suggest it had not reduced corruption, because corruption did fall, but this impact was offset by some other factor (corruption was replaced by legal lobbying that as effectively reduced returns to utility investment, for example).

This may be a problem for those concerned with the morality of individuals as judged by the legal status of their actions. It is of lesser concern to those more broadly interested in development outcomes. A governance intervention that improves sector outcomes is to be welcomed whatever the mechanism by which it accomplishes that feat. Conversely, a governance regime which, for example, reduces illegal payoffs by legalizing them might be considered less successful from a broad-based perspective. Furthermore, to the extent 
we are able to judge empirically, it appears that improved governance regimes are usually associated with lower levels of corruption (Kaufmann et. al. 2006). Governance interventions which increase levels of corruption while improving sector outcomes are likely to be comparatively rare, and should be of even less concern.

\section{The Central Role of Sector Reform}

Again, available results on corruption in infrastructure match cross-sectoral findings regarding where corruption is likely to be more common, and might suggest broad reform approaches to reduce the extent and impact of that corruption -transparency, participation, competition, reduced discretionary powers, removal of unnecessary regulation, improved financial management and extended auditing (Cavill and Sohail, 2007, Seldadyo and de Haan, 2005, Lederman et. al., 2005). These interventions have long been elements of a sector reform agenda concerned with broader institutional development.

Having said that measuring governance inputs and sector outputs is a comparatively straightforward way to evaluate both the state of governance and the impact of governance reform in utilities, it should be noted that it is a process that is still very much in its early days, and not itself free of controversy (see Estache, 2006, for a review of some of the issues). Nonetheless, patterns do appear to be emerging regarding elements of a broader governance agenda covering energy, water and (in particular) telecommunications. It does appear that private and especially competitive provision is broadly associated with greater efficiency and improved outcomes across utilities.

The evidence is unambiguous in telecommunications. A global study based on experience of 86 countries from 1985 to 1999 found that sector reform was associated with an 8 percent higher level of mainline provision and a 21 percent higher level of labor productivity compared with nonreformed countries (Rathindran et. al., 2002). Another recent review found that the average annual growth rate of fixed line rollout was 50 percent higher in liberalized telecom markets with a separate regulator than in countries with a state monopoly and no separate regulator (Qiang and Pitt 2003)

It is also clear from numerous studies that competitive provision reduces telecommunications costs. Rossotto et. al. (2004) finds that fully competitive international markets see international call costs 66 percent lower than those countries with partial competition. Prices for a basket of fixed telecommunications services are 20 percent lower in developing countries with competition than countries where there is a monopoly in provision (World Bank, 2005).

Overall satisfaction with private competitive provision in telecommunications is also suggested by responses to enterprise surveys in the developing world about the constraints to the growth of businesses, including a question regarding the seriousness of

\footnotetext{
8 "Not liberalized" was defined as having monopoly or duopoly operator for basic line services.

"liberalized" markets have three or more operators.
} 
constraints created by inadequate telecommunications services. The average worldwide for the 45 countries for which we have data is that 9.8 percent of companies rate telecommunications as a major or very severe constraint to doing business. In countries where more than 50 percent of the incumbent telecommunications operator was in private hands, only an average of 5.4 percent of firms saw telecommunications as a major or severe constraint - as compared to nearly 16 percent in countries where the incumbent was fully state-owned (World Bank, 2005).

There is considerable evidence of an impact of private provision in energy and water, as well -at least as regards efficiency. The cities in Kolkata and Mumbai have long been served by private electricity utilities, and commercial losses in those cities are between 12-15 percent as compared to 30-35 percent with state-owned electricity utilities in India, for example (Gulati and Rao, 2006). Estache and Kouassi (2002) find that private provision is linked to greater efficiency in African Water utilities. Gassner et. al. (2007) in the most comprehensive analysis of private and public provision of water and electricity in developing countries carried out to date, report that private sector participation is associated with an increase in quality as measured by the length of uninterrupted daily supply, an improvement in collection rates, a decline in operational losses (by between one tenth and one third in electricity), improved labor productivity and an expanded capital base. Results on formal service price and rollout were inconclusive. However there is some evidence that private provision may reduce the extent of informal payments for service. Private competition reduced the level of bribes paid to utilities for services in a study of 21 transition economies (Clarke and Xu, 2004).

Regarding initial privatizations, concessioning and licensing, the importance of competitive, transparent approaches, discussed with regard to water in Jakarta, is reinforced by Malaysia's experience with fifteen independent power producers authorized without competitive tender -electricity costs around fifty percent more than that provided by state-owned plants, but the contract conditions demand purchase (Smith, 2003).

The introduction of private provision, especially absent competition, requires improved governance both in the initial privatization but also in the regulation of providers. Absent a strong regulator, the effects of competition in telecommunications can be muted and the impact of privatization can be completely dissipated (Wallsten, 1999). Andres et. al. (2007) find that regulators in Latin America that were established under law, well funded by regulatory levy, and with a fixed-term regulatory commission screened by legislators were considerably better at aligning cost of capital and rate of return. Gasmi et. al. (2006) find that independent regulation (with tenure) financed from operator contributions with the power to make decisions over licensing interconnection that could only be overruled by the courts as well as transparency --open meetings and textual explanations of decisions-- produce better outcomes in telecoms in terms of network rollout. 9

\footnotetext{
${ }^{9}$ Despite this, a PPIAF survey of regulators in 2005 found that less than 30 percent of regulators currently
} publish contracts and licenses) (Bertolini, 2006). 71 percent of East Asian regulators disclosed 
Even with these features, regulators in developing countries will have comparatively limited capacity, suggesting the importance of simplicity in regulatory design. The US Federal Communications Commission budget of $\$ 304$ million, for example, is probably larger than total telecoms sector revenues in around 89 of 139 low and middle income countries for which we have data. ${ }^{10} \mathrm{~A}$ focus on a few precise and simple regulatory instruments over theoretically more efficient but complex rules is particularly vital in countries with limited regulatory capacity (Besant-Jones, 2006).

Similar lessons appear to apply in electricity and water. In Latin America, approximately 90 percent of water privatizations and over half of energy privatizations over the 1990s were in the form of concessions, which were frequently renegotiated (in three quarters of cases in water), on average after just over two years of signature. Renegotiation was far less likely in countries with a pre-existing regulator established under law, where concessionaires were selected based on price for concession award rather than lowest tariff, and where tariff regulation was based on rate of return rather than a price cap (Estache et. al. 2003). Incidence of early contract renegotiation was 40 percent in cases where the regulatory framework was embedded in the concession contract compared to 17 percent where the regulatory framework was embedded in law (Guasch, 2004). It is worth noting that, with infrastructure concessions, there is evidence that contract renegotiation substitutes for direct negotiation of initial concessions, with 46 percent of competitively-awarded contracts renegotiated compared to 8 percent of contracts awarded through bilateral negotiations -this suggests the importance of contract clarity regarding triggers and implementation methods for renegotiation overseen by a neutral, transparent body (Guash, 2004).

Gassner et. al. (2007) also find that the impact of the mere presence of a regulator is muted, suggesting the need for considerable institution-building beyond legal authorization. Furthermore, there is evidence that the independent regulatory model may be inappropriate at least in some sectors in smaller economies, suggesting the need for alternate approaches that combine transparency with limited discretion. One example of an institutionally simple approach is to combine a monitoring agent within the appropriate ministry with provider contracts that define service standards and tariff setting (or operator renumeration). This removes the need for an independent regulatory agency and has worked with some success in countries including Senegal, Cote d'Ivoire and Vanuatu (Ehrhardt et al 2007).

One important step towards regulatory simplicity is to remove overlap between agencies. In the Philippines, an independent water regulator had authority to set standards and apply rules regarding financial renumeration in the sector. But the contracts governing private provision of water in Manila also set out standards regarding financial arrangements and standards. This confusion led to public disputes, complex appeals processes and, in the end, political intervention in tariff-setting (Ehrhardt et. al., 2007).

procedures and decisions, while 42 percent disclosed licenses and contracts, in a 2004 survey (Muzzini, 2006).

${ }^{10}$ Estimated on the basis that telecoms revenues are approximately two percent of 2005 market GDP. 
Regardless of the apparent advantages of competitive private provision under light but effective regulation, the majority of utilities in developing countries remain in government ownership. The lessons on improved governance appear to be less clear in this area. Many approaches have not been carefully evaluated, and what we do know suggests mixed impacts (Irwin and Yamamoto, 2004, Gomez-Ibanez, 2006).

Nonetheless, where full privatization is not an option, state-owned enterprises may still benefit from a number of internal and external governance measures, even if hopes for dramatic improvement should be tempered.

Corporatization is designed to strengthen SOE autonomy, through creation of a separate statutory authority, with a distinct legal identity, separate accounts and its own board of directors (preferably including members from the private sector and stakeholder groups as well as government) (Gomez-Ibanez, 2006). Management is given considerable autonomy in areas such as HR, financial management, pricing (under regulation) and service provision. Measures of autonomy in these areas have been associated with considerably better performance in terms of coverage and quality in an econometric analysis of water utilities from Africa, Asia and the Middle East (Braadbaart et. al., 2007). In some countries, an SOE audit committee is chaired by an independent nonexecutive director and externally audited accounts meeting International Financial Reporting Standards (IFRS) are published. Additionally, SOEs that borrow from the private sector without the benefit of a government guarantee will face the scrutiny of lenders and credit-rating agencies. Listing a minority of shares will create another level of monitoring by shareholders.

On the demand side of governance, citizen's charters can clarify the standards that consumers can expect in terms of quality, timeliness, cost and coverage of services. These can be based on regulatory standards where appropriate but should be actively disseminated to the public alongside information on complaint and redress mechanisms. Citizen report cards survey households about their experience and satisfaction interacting with public officials and receiving government services. These can be combined with a social audit where official reports of works and expenditures are reviewed and compared to the results of customer surveys.

One recent example of SOE reform to improve utility governance involved the Phnom Penh Water Supply Authority. The program included putting in a management team with performance-based incentives, corporatization, water meters installation and automated billing and accounting, customer surveys and a new tariff structure based on costrecovery models all accompanied by a public information campaign (World Bank, 2006).

A further area of focus for governance is on improving the quality of investment -a focus that extends beyond utilities to government budgeting and planning exercises. Within utilities, methods that ensure new infrastructure is likely to deliver development results include the use of output-based approaches, which pay utilities ex post for providing services based on the actual delivery of those services to targeted populations (Kenny and Mumssen, 2007). Other tools to ensure quality outcomes include the use of consumer 
and civil society involvement in project selection and design, the procurement process and oversight of project execution as well as physical audits of projects using independent third party monitors.

\section{Conclusion}

If utilities deliver quality services efficiently, corruption can have had had little effect on development outcomes. And because efficient, quality service provision implies the presence of few rents to finance corrupt payments, it suggests that the extent of corruption must be limited. If there are few staff on the payroll per connection and yet the connections work well, this suggests there must be few ghost workers. If transmission and distribution losses are limited, this implies low levels of collusive theft -and so on. By and large, the anti-corruption agenda is the sector reform agenda, then.

Again, with new investments, to create rents, construction firms or utilities colluding with the government officials who oversee them can increase prices beyond the cost of construction or reduce costs through low quality or under-delivering build-out. They can collude to raise the contract price beyond cost, for example, or construct poor-quality piping. It is these rent-creating outcomes which are the 'development impact' of corruption -but preventing such outcomes through tools such as better oversight or output-based approaches also removes the rents that finance corrupt payments.

Of course there are some utility management actions that can be taken that are specifically aimed at reducing corruption in utilities. For example, as part of a process of enterprise reform, a number of human resources tools can be used that might help to improve performance and reduce corruption amongst public officials including training on codes of conduct, whistleblower protection, improved disciplinary procedures, transferring staff in posts considered 'at risk,' random checks on performance by investigators posing as customers and reducing anonymity through name tags and other information disclosure (Sohail and Cavill, 2007). Again, it should be noted that, when it comes to procurement of new infrastructure, there is a corruption-specific agenda, involving monitoring of the procurement process for 'red flags' -indicators of collusion and corruption such as bunching of bids - and investigation of suspicious cases.

At the same time, the bulk of what may be good for reducing corruption (to the extent that we know what that is) is likely to be part of a traditional reform agenda covering sector structure, regulatory models, state-owned enterprise reform and government investment planning.

This is fortunate, because our ability to measure corruption in utilities in particular is very weak. If we were left to rely on these measures alone to determine success and failure in our anticorruption efforts, we would be very much in the dark. Governance interventions should and can more easily be judged on their impact on sector outcomes, and our measurement efforts should be focused on these intervention and outcome measures. 


\section{Bibliography}

Andres, L., J. Guasch and S. Straub (2007) Does Regulation and Institutional Design Matter for Infrastructure Sector Performance? Mimeo, World Bank.

Bertolini, L. (2006) how to Improve Regulatory Transparency PPIAF Gridlines Note No. 11.

Besant-Jones, J. (2006) Reforming Power Markets in Developing Countries: What Have We Learned? World Bank Energy and Mining Sector Board Discussion Paper 19.

Braadbaart, O., N. Eybergen and J. Hoffer (2007) Managerial Autonomy: Does it Matter for the Performance of Water Utilities? Public Administration and Development 27111 121.

Castalia (2005) Sector Note on Water Supply and Sanitation for the Infrastructure in East Asia and the Pacific Flagship. Mimeo, World Bank.

Clarke, G. and L. Xu (2004) Privatization, Competition and Corruption: how Characteristics of Bribe Takers and Payers Affect Bribes to Utilities, Journal of Public Economics 88.

Davis, J. (2003) Corruption in Public Service Delivery: Experience from South Asia's Water and Sanitation Sector, World Development 32, 1.

Ehrhardt, D., E. Groom, J. Halpern and S. O’Connor (2007) Economic Regulation of Urban Water and Sanitation Services: Some Practical Lessons World Bank Water Sector Board Discussion Paper No. 9.

Estache, A. and E. Kouassi (2002) Sector Organization, Governance and the Inefficiency of African Water Utilities world Bank Policy Research Working Paper 2890

Estache, A., J. Guasch and L. Trujillo (2003) Price Caps, Efficiency Payoffs and Infrastructure Contract Renegotiation in Latin America World Bank Policy Research working Paper 3129.

Estache, A., A. Goicoechea and L. Trujillo (2006) Utilities Reform and Corruption in Developing Countries, mimeo, World Bank.

Estache, A. (2006) PPI Partnerships Vs PPI Divorces in LDCs, Review of Industrial Organization 29 3-26.

Fay, M. and T. Yepes (2003) Investing in Infrastructure: What is Needed from 2000 to 2010 World Bank Policy Research Working Paper 3102

Franceys, R. (2005) Charging to Enter the Water Shop? The Costs of Urban Water Connections for the Poor Water Science and Technology: Water Supply 5, 6, 209-216.

Gasmi, F., P. Noumba and L. Virto (2006) Political Accountability and Regulatory Performance in Infrastructure Industries: An Empirical Análisis, World Bank Policy Research Working Paper 4101.

Gassner, K., A. Popov and N. Pushak (2007) An Empirical Assessment of Private Sector Participation in Electricity and Water Distribution in Developing Countries, mimeo, World Bank. 
Gomez-Ibanez, J. (2006) Alternatives to Privatization Revisited: The Options for Infrastructure, mimeo, World Bank.

Guasch, J. L. (2004) Granting and Renegotiating Infrastructure Concessions: Doing it Right Washington DC: World Bank.

Gulati, M. and M. Rao (2006) Checking Corruption in the Electricity Sector, mimeo, World Bank.

Irwin, T. and C. Yamamoto (2004) Some Options for Improving the Governance of State-Owned Electricity Utilities, Energy and Mining Sector Board Discussion Paper No. 11.

Kaufmann, D., A. Kraay and M. Mastruzzi (2006) Measuring Governance Using CrossCountry Perceptions Data in S. Rose-Ackerman International Handbook on the Economics Corruption. Edward Elgar.

Kenny, C. and Y. Mumssen (2007) Output Based Aid as a Tool to Reduce the Impact of Corruption on Development Outcomes in Infrastructure, mimeo, World Bank.

Kenny, C. (2006) Measuring and Reducing the Impact of Corruption in Infrastructure, World Bank Policy Research Working Paper 4099.

Konar, S. and M. Cohen (1997) Information as Regulation: The Effect of Community Right to Know Laws and Toxic Emissions, Journal of Environmental Economics and Management 32.

Lederman, D., N. Loayza and R. Soares (2005) Accountability and Corruption: Political Institutions Matter Economics and Politics 17, 1.

Lewis, M. (2006) Governance and Corruption in Public Health Care Systems, Center for Glboal Development Working Paper 78.

Lovei, L. and D. Whittington (1991) Rent Seeking in Water Supply World Bank Infrastructure and Urban Development Department Discussion Paper 1991.

Muzzini, E. (2006) Consumer Participation in Infrastructure Regulation: Evidence from East Asia and Pacific Region. World Bank Working Paper No. 66.

Olken, B. (2006) Corruption Perceptions vs. Corruption Reality NBER Working Paper 12428 .

Olken, B. (2004) Monitoring Corruption: Evidence from a Field Experiment in Indonesia, NBER Working Paper 11753.

Qiang, C. and A. Pitt (2004) Contribution of ICT to Growth World Bank Working Paper.

Rathindran, R., C. Fink and A. Mattoo (2002) An Assessment of Telecommunications Reform in Developing Countries World Bank Working Paper No. 2909

Reinikka, R. and J. Svensson (2006) Using Micro-Surveys to Measure and Explain Corruption, World Development, 34, 2.

Rossotto, C., B. Wellenius, A. Lewin, and C. Gómez, (2004) Competition In International Voice Communications, World Bank Working Paper No. 42. 
Satyanand, P. (2007) Requiring Indian Utilities to Report: Harnessing Disclosure Legislation ot Improve Water and Sanitation Service, mimeo, World Bank.

Seldadyo, H. and J. de Haan (2005) The Determinants of Corruption: A Reinvestigation mimeo, University of Groningen.

Seligson, M. (2005) The Measurement and Impact of Corruption Victimization: Survey Evidence from Latin America World Development 34, 2.

Smith, T. (2003) Privatising Electric Power in Malaysia and Thailaind: Politics and Infrastructure Development Policy Public Administration and Development 23.

Sohail, M. and S. Cavill (2007) Partnering to Combat Corruption in Infrastructure Services: A Tool-kit, mimeo, Loughborough University

Tanzi, V. and H. Davoodi (1998) Roads to Nowhere: How Corruption in Public Investment Hurts Growth, IMF Economic Issues No. 12.

World Bank (2006) Infrastructure at the Crossroads: Lessons from 20 Years of World Bank Experience, Washington DC: World Bank. 


\section{Table One}

Indicator

Value of gift expected to secure

government contract (\% of contract)

Firms expected to give gifts to get a

phone connection (\%)

Firms expected to give gifts to get a electrical connection (\%)

Firms expected to give gifts to get a water connection (\%)

Firms expected to give gifts to get a construction permit (\%)

$\%$ Fixed telco state owned

Local Telecommunications Competition

Transparency International CPI

Corruption ( $\%$ of managers surveyed

ranking this as a major constraint)

Business disclosure index $(0=$ less

disclosure to $7=$ more disclosure)

Electric power transmission and

distribution losses (\% of output)

Electricity (\% of managers surveyed

ranking this as a major constraint)

Log GDP per capita, PPP (constant 2000

international \$)

Private investment in water and sanitation

(\% 2003 GDP) 1999-2003

Private investment in energy $(\% 2003$

GDP) 1999-2003

Private investment in telecoms 1999-2003

(\% 2003 GDP)

Telephone mainlines, waiting list (\%

mainlines)

Control of Corruption

Improved Water \% Population

Mobile phone subscribers (per 1,000

people)

Electric power consumption (kWh per

capita)

\section{Average Standard Observations Source Deviation}

\begin{tabular}{|c|c|c|c|}
\hline 2.5 & 2.6 & 51 & $\begin{array}{l}\text { Enterprise } \\
\text { surveys }\end{array}$ \\
\hline 24 & 31 & 23 & $\begin{array}{l}\text { surveys } \\
\text { Enterprise }\end{array}$ \\
\hline 25 & 29 & 23 & $\begin{array}{l}\text { surveys } \\
\text { Enterprise }\end{array}$ \\
\hline 18 & 24 & 16 & $\begin{array}{l}\text { surveys } \\
\text { Enterprise }\end{array}$ \\
\hline 19 & 17 & 17 & surveys \\
\hline 51 & 41 & 22 & ITU \\
\hline 1.0 & 0.8 & 21 & $\begin{array}{l}\text { ITU } \\
\text { Transparency }\end{array}$ \\
\hline 3.1 & 1.0 & 58 & $\begin{array}{l}\text { International } \\
\text { Enterprise }\end{array}$ \\
\hline 33 & 19 & 48 & $\begin{array}{l}\text { surveys } \\
\text { Doing }\end{array}$ \\
\hline 3.0 & 1.7 & 55 & $\begin{array}{l}\text { Business } \\
\text { World Bank }\end{array}$ \\
\hline 17 & 9 & 51 & $\begin{array}{l}\text { WDI } \\
\text { Enterprise }\end{array}$ \\
\hline 20 & 18 & 48 & $\begin{array}{l}\text { surveys } \\
\text { World Bank }\end{array}$ \\
\hline 8.3 & 0.9 & 56 & WDI \\
\hline 0.00 & 0.01 & 58 & PPI Database \\
\hline 0.02 & 0.03 & 58 & PPI Database \\
\hline 0.03 & 0.03 & 58 & $\begin{array}{l}\text { PPI Database } \\
\text { World Bank }\end{array}$ \\
\hline 0.2 & 0.3 & 43 & WDI \\
\hline-0.4 & 0.5 & 58 & $\begin{array}{l}\text { WBI } \\
\text { World Bank }\end{array}$ \\
\hline 79 & 18 & 50 & $\begin{array}{l}\text { WDI } \\
\text { World Bank }\end{array}$ \\
\hline 301 & 293 & 54 & $\begin{array}{l}\text { WDI } \\
\text { World Bank }\end{array}$ \\
\hline 2003 & 1727 & 52 & WDI \\
\hline
\end{tabular}

Sources: Enterprise surveys: http://www.enterprisesurveys.org/ (accessed 06/07/2006) Doing Business: http://www.doingbusiness.org/ (accessed 06/07/2006) ITU: Trends in Telecommunications Reform Geneva: ITU, 2006, World Bank WDI: World Development Indicators, WBI: World Bank Institute Worldwide Governance Indicators, 2006. 
Table Two

\begin{tabular}{|c|c|c|c|c|c|c|}
\hline Intercept & $\begin{array}{c}\log \\
\text { GDP/capita }\end{array}$ & $T I C P I$ & $\begin{array}{c}\text { Corruption } \\
\text { \%\% of } \\
\text { managers } \\
\text { surveyed } \\
\text { ranking this } \\
\text { as a major } \\
\text { constraint) }\end{array}$ & $\begin{array}{l}\text { Value of gift } \\
\text { expected to } \\
\text { secure } \\
\text { government } \\
\text { contract (\% } \\
\text { of contract) }\end{array}$ & $\begin{array}{c}\text { Average } \\
\text { Firms } \\
\text { Expected to } \\
\text { Give Gifts to } \\
\text { Get a Phone } \\
\text { /Electrical } \\
\text { Water } \\
\text { connection }\end{array}$ & R Square \\
\hline \multicolumn{7}{|c|}{ Private investment in energy, telecoms, water and sanitation 1999-2003 (\% 2003 GDP) } \\
\hline $\begin{array}{r}-1.82 \\
0.74\end{array}$ & $\begin{array}{l}0.49 \\
0.54\end{array}$ & $\begin{array}{l}0.90 \\
0.23\end{array}$ & & & & 0.09 \\
\hline $\begin{array}{r}-0.13 \\
0.03\end{array}$ & $\begin{array}{l}0.02 \\
0.00\end{array}$ & & $\begin{array}{r}0.00 \\
0.15\end{array}$ & & & 0.19 \\
\hline $\begin{array}{r}-6.16 \\
0.26\end{array}$ & $\begin{array}{l}1.24 \\
0.06\end{array}$ & & & $\begin{array}{c}0.49 \\
0.03\end{array}$ & & 0.14 \\
\hline $\begin{array}{r}10.43 \\
0.31\end{array}$ & $\begin{array}{r}-0.60 \\
0.63\end{array}$ & & & & $\begin{array}{r}-0.01 \\
0.68\end{array}$ & 0.02 \\
\hline \multicolumn{7}{|c|}{ Transmission and distribution losses } \\
\hline $\begin{array}{r}38.74 \\
0.01\end{array}$ & $\begin{array}{r}-1.71 \\
0.40\end{array}$ & $\begin{array}{r}-2.29 \\
0.19\end{array}$ & & & & 0.14 \\
\hline $\begin{array}{r}32.02 \\
0.06\end{array}$ & $\begin{array}{r}-2.17 \\
0.23\end{array}$ & & $\begin{array}{r}0.11 \\
0.21\end{array}$ & & & 0.14 \\
\hline $\begin{array}{r}43.52 \\
0.05\end{array}$ & $\begin{array}{r}-3.32 \\
0.20\end{array}$ & & & $\begin{array}{r}0.05 \\
0.49\end{array}$ & & 0.13 \\
\hline $\begin{array}{r}48.69 \\
0.00\end{array}$ & $\begin{array}{r}-3.81 \\
0.02\end{array}$ & & & & $\begin{array}{c}0.09 \\
0.86\end{array}$ & 0.13 \\
\hline \multicolumn{7}{|c|}{ Log Electric power consumption (kWh per capita) } \\
\hline $\begin{aligned}-2.84 \\
0.02\end{aligned}$ & $\begin{array}{l}1.21 \\
0.00\end{array}$ & $\begin{array}{r}-0.08 \\
0.60\end{array}$ & & & & 0.64 \\
\hline $\begin{array}{r}0.62 \\
0.62\end{array}$ & $\begin{array}{l}0.87 \\
0.00\end{array}$ & & $\begin{array}{c}-0.02 \\
0.00\end{array}$ & & & 0.74 \\
\hline $\begin{aligned}-1.08 \\
0.34\end{aligned}$ & $\begin{array}{l}1.00 \\
0.00\end{array}$ & & & $\begin{array}{c}-0.08 \\
0.04\end{array}$ & & 0.63 \\
\hline $\begin{aligned}-4.94 \\
0.00\end{aligned}$ & $\begin{array}{l}1.38 \\
0.00\end{array}$ & & & & $\begin{array}{l}0.00 \\
0.50\end{array}$ & 0.84 \\
\hline \multicolumn{7}{|c|}{ Electricity (\% of managers surveyed ranking this as a major business constraint) } \\
\hline $\begin{array}{r}125.00 \\
0.00\end{array}$ & $\begin{aligned}-12.85 \\
0.00\end{aligned}$ & $\begin{array}{l}0.69 \\
0.79\end{array}$ & & & & 0.40 \\
\hline $\begin{array}{r}92.01 \\
0.00\end{array}$ & $\begin{array}{r}-10.11 \\
0.00\end{array}$ & & $\begin{array}{l}0.33 \\
0.00\end{array}$ & & & 0.56 \\
\hline $\begin{array}{r}112.91 \\
0.00\end{array}$ & $\begin{array}{r}-11.61 \\
0.00\end{array}$ & & & $\begin{array}{r}1.05 \\
0.15\end{array}$ & & 0.43 \\
\hline $\begin{array}{r}122.93 \\
0.00\end{array}$ & $\begin{array}{r}-11.53 \\
0.00\end{array}$ & & & & $\begin{array}{r}-0.05 \\
0.55\end{array}$ & 0.35 \\
\hline \multicolumn{7}{|l|}{ Improved Water \% Pop } \\
\hline $\begin{array}{r}-48.85 \\
0.02\end{array}$ & $\begin{array}{r}16.60 \\
0.00\end{array}$ & $\begin{array}{r}-2.16 \\
0.53\end{array}$ & & & & 0.49 \\
\hline $\begin{array}{r}-41.00 \\
0.11\end{array}$ & $\begin{array}{r}14.95 \\
0.00\end{array}$ & & $\begin{array}{l}0.00 \\
0.97\end{array}$ & & & 0.44 \\
\hline $\begin{array}{r}-32.80 \\
0.11\end{array}$ & $\begin{array}{r}13.98 \\
0.00\end{array}$ & & & $\begin{array}{r}-0.20 \\
0.78\end{array}$ & & 0.46 \\
\hline $\begin{array}{r}1.52 \\
0.96\end{array}$ & $\begin{array}{r}10.43 \\
0.01\end{array}$ & & & & $\begin{array}{r}-0.46 \\
0.00\end{array}$ & 0.73 \\
\hline \multicolumn{7}{|c|}{ Telephone mainlines, waiting list (\% mainlines) } \\
\hline $\begin{array}{r}0.76 \\
0.07\end{array}$ & $\begin{array}{c}-0.07 \\
0.28\end{array}$ & $\begin{array}{c}-0.02 \\
0.77\end{array}$ & & & & 0.08 \\
\hline $\begin{array}{r}0.99 \\
0.00\end{array}$ & $\begin{array}{r}-0.10 \\
0.00\end{array}$ & & $\begin{array}{l}0.00 \\
0.34\end{array}$ & & & 0.26 \\
\hline $\begin{array}{r}0.45 \\
0.01\end{array}$ & $\begin{array}{c}-0.04 \\
0.05\end{array}$ & & & $\begin{array}{c}-0.01 \\
0.34\end{array}$ & & 0.12 \\
\hline $\begin{array}{c}-0.31 \\
0.81\end{array}$ & $\begin{array}{l}0.05 \\
0.75\end{array}$ & & & & $\begin{array}{r}0.01 \\
0.20\end{array}$ & 0.18 \\
\hline \multicolumn{7}{|c|}{ Log Mobile phone subscribers (per 1,000 people) } \\
\hline $\begin{aligned}-5.77 \\
0.00\end{aligned}$ & $\begin{array}{l}1.27 \\
0.00\end{array}$ & $\begin{array}{l}0.09 \\
0.45\end{array}$ & & & & 0.79 \\
\hline $\begin{aligned}-7.60 \\
0.00\end{aligned}$ & $\begin{array}{l}1.47 \\
0.00\end{array}$ & & $\begin{array}{l}0.01 \\
0.03\end{array}$ & & & 0.79 \\
\hline $\begin{array}{r}-4.50 \\
0.00\end{array}$ & $\begin{array}{l}1.16 \\
0.00\end{array}$ & & & $\begin{array}{l}0.01 \\
0.68\end{array}$ & & 0.81 \\
\hline $\begin{array}{c}-2.85 \\
0.02\end{array}$ & $\begin{array}{l}0.97 \\
0.00\end{array}$ & & & & $\begin{array}{r}0.00 \\
0.50\end{array}$ & 0.74 \\
\hline
\end{tabular}




\section{Figure One}

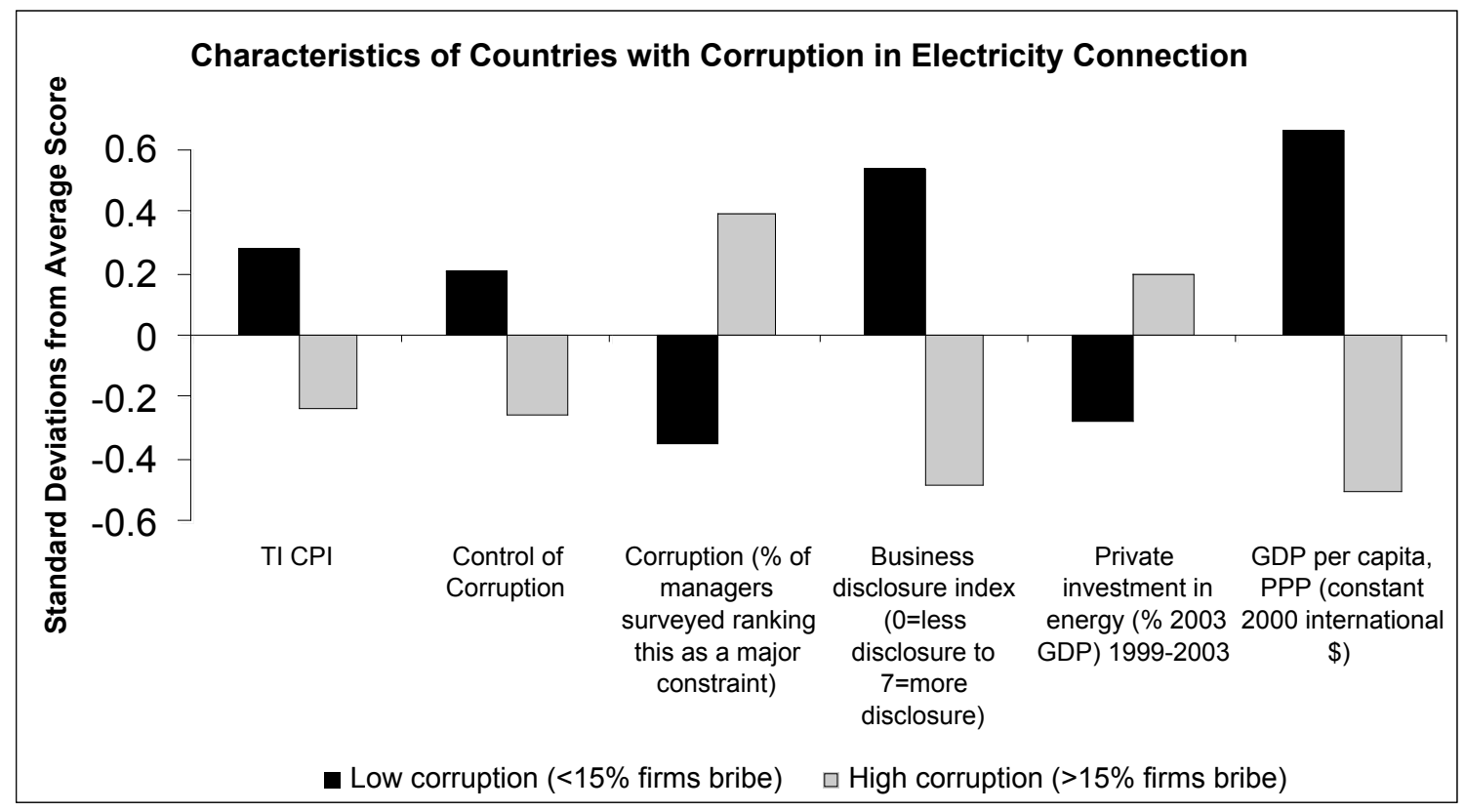

Figure Two

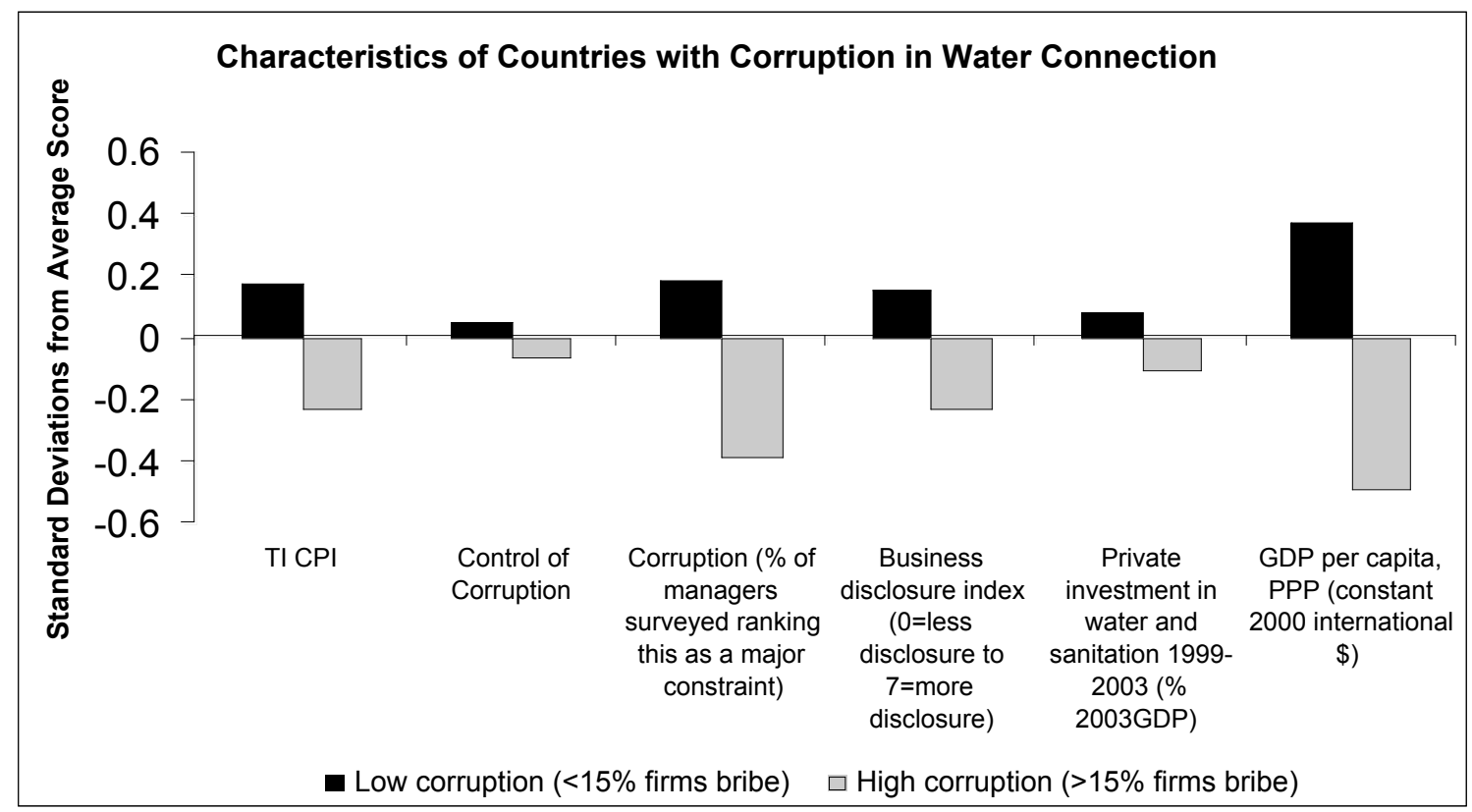




\section{Figure Three}

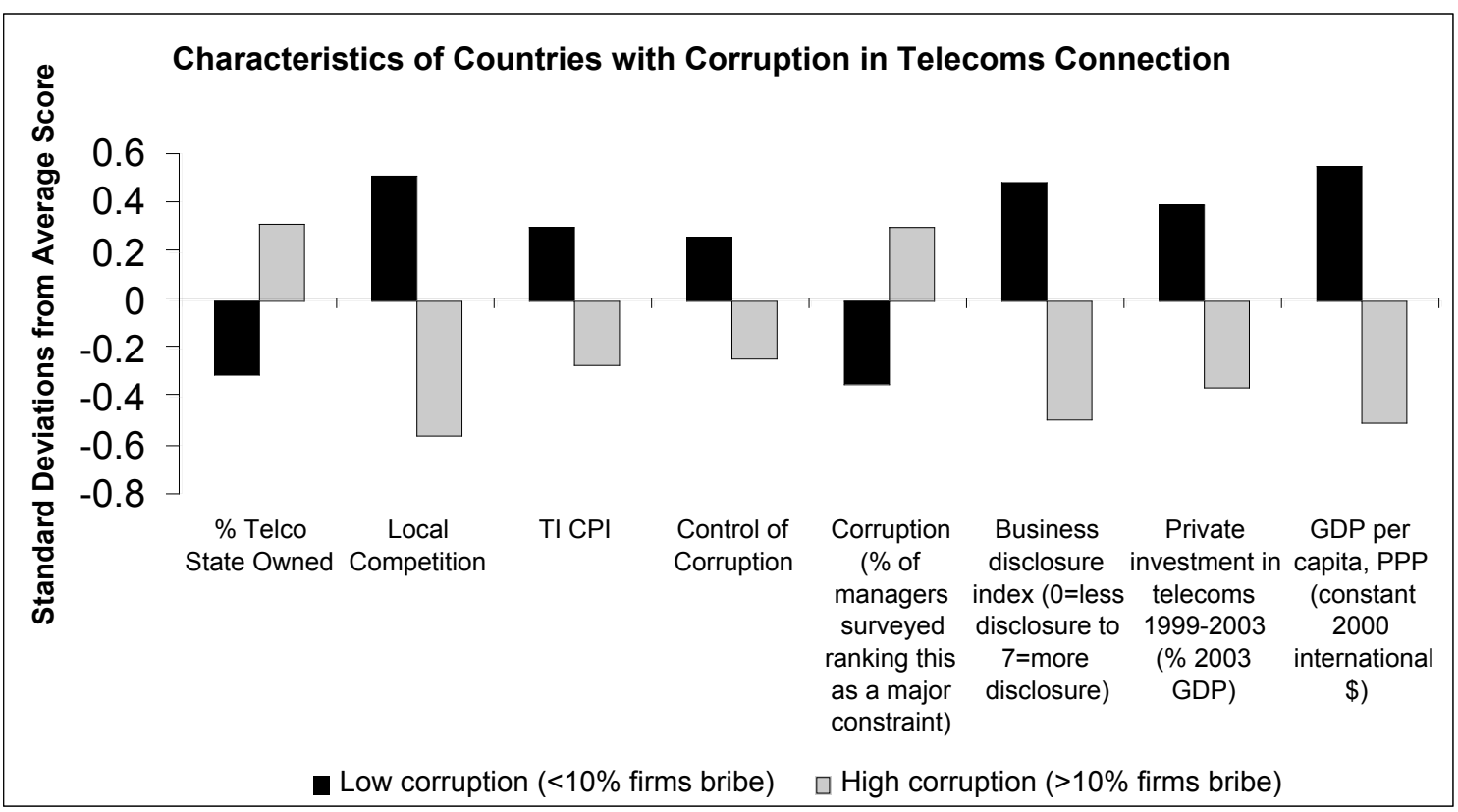

